\title{
Pengaruh Suhu Udara terhadap Fekunditas Dan Perkembangan Pradewasa Lalat Rumah (Musca Domestica)
}

\section{The Influence of Temperature on Fecundity and Immature Development of House Fly (Musca domestica)}

\author{
lif Miftahul Ihsan ${ }^{1^{*}}$, Rini Hidayati ${ }^{2}$, Upik Kesumawati Hadi $^{3}$ \\ ${ }^{1}$ Pusat Teknologi Lingkungan, Badan Pengkajian dan Penerapan Teknologi Puspiptek, Serpong, \\ Tangerang Selatan 15314 \\ ${ }^{2}$ Geofisika dan Meteorologi, FMIPA IPB JI. Meranti Wing 19 Lv. 4 Kampus IPB Darmaga, Bogor 16880 \\ ${ }^{3}$ Parasitologi dan Entomologi Kesehatan, FKH IPB Jl. Agatis Kampus IPB Darmaga, Bogor 16880 \\ iif.miftahul@bppt.go.id
}

\begin{abstract}
The house fly (Musca domestica) is an insect that is often found in human habitat and acts as a transmitter of disease. This study is a laboratory observation that aimed to analyze the effects of the air temperature to the survival rate and developmental period (longevity) of immature house flies. The survival rate and developmental period of immature house flies were observed at temperatures of $16,27,31$, and $39{ }^{\circ} \mathrm{C}$ as well as the ambient temperature as a control. The results of the immature house flies in the growth chamber showed the lowest and the highest survival rate occurred at $16{ }^{\circ} \mathrm{C}$ and $27^{\circ} \mathrm{C}$ respectively. The influence of the temperature to the survival rate and the development rate of immature house flies is in the form of quadratical pattern, while the relationship between the increasing temperature and the decreasing developmental period of immature house flies forms an exponential equation. Analysis shows the optimum temperature for the survival rate and the development rate of the immature house flies occurred at $28{ }^{\circ} \mathrm{C}$.
\end{abstract}

Keywords: house fly, immature development rate, survival rate, temperature

\begin{abstract}
ABSTRAK
Lalat rumah merupakan serangga yang banyak dijumpai di sekitar pemukiman manusia dan berperan sebagai penyebar penyakit. Studi ini bertujuan untuk menganalisis pengaruh suhu udara terhadap daya tahan hidup dan periode perkembangan lalat rumah pradewasa. Pengamatan dilakukan pada suhu 16, 27, 31, dan $39 \stackrel{\circ}{\circ} \mathrm{C}$ serta suhu lingkungan (ambien) sebagai suhu kontrol. Hasil pengamatan menunjukkan bahwa daya tahan hidup lalat rumah pradewasa di ruang terkontrol yang terendah dan tertinggi terjadi terjadi pada suhu $16{ }^{\circ} \mathrm{C}$ dan $27 \stackrel{\circ}{\circ} \mathrm{C}$. Pola hubungan suhu dengan daya tahan hidup dan laju perkembangan lalat rumah pradewasa per hari membentuk persamaan kuadratik, sedangkan pengaruh peningkatan suhu terhadap penurunan laju perkembangan lalat rumah pradewasa mengikuti persamaan eksponensial. Hasil analisis data menunjukkan bahwa daya tahan hidup dan laju perkembangan tertinggi dari lalat rumah pradewasa terjadi pada suhu optimum $28^{\circ} \mathrm{C}$.
\end{abstract}

Kata kunci: lalat rumah, perkembangan pradewasa, daya tahan hidup, suhu

\section{PENDAHULUAN}

Penyakit zoonosis merupakan penyakit yang dapat diltularkan oleh hewan kepada manusia. Penyakit zoonosis banyak mendapat perhatian global seiring dengan pemanasan global. Kerugian yang ditimbulkan oleh penyakit zoonosis berdampak luas, karena selain merugikan kesehatan manusia secara langsung 
juga mengancam keamanan dan kemandirian pangan, karena penyakit zoonosis juga dapat menyerang binatang ternak ${ }^{(1)}$. Beberapa jenis penyakit zoonosis dapat ditularkan oleh hewan jenis serangga lalat, antara lain lalat rumah (Musca domestica).

Cuaca/iklim merupakan salah satu faktor lingkungan yang pengaruhnya besar terhadap pertumbuhan dan perkembangan serangga khususnya lalat. Serangga ini sering berpindahpindah ke tempat yang kotor untuk kemudian berpindah ke makanan atau tubuh manusia atau hewan karena hidup dan tersebar pada populasi padat dan dapat berperan sebagai polinator serta dapat bertindak sebagai vektor pada banyak organisme pathogen ${ }^{(2)}$.

Lalat rumah berperan dalam penyebaran penyakit seperti diare, disentri, kolera, demam tifoid dan paratifoid karena menyebarkan kotoran ke makanan, minuman, sayuran, buahbuahan, maupun ke tubuh ternak. Lalat umah (M domestica) mempunyai kemampuan memindahkan berbagai macam mikroorganisme dari tempat yang dihinggapinya ke tempat lain yang dihinggapi kemudian. Ada 7 genus jamur dari tubuh dan ususnya, yaitu Acremonium, Aspergillus, Debaryomyces, Hanseniaspora, Fusarium, Penicillium, dan Geotrichum ${ }^{(3)}$. Lalat rumah tidak menggigit binatang ternak tetapi sangat mengganggu sehingga bisa mengurangi kenyamanan yang pada akhirnya dapat menurunkan produksi. Demam tifoid dan paratifoid merupakan salah satu masalah kesehatan yang penting yang dapat menular dan menyerang banyak orang sehingga menimbulkan wabah. Berdasarkan profil kesehatan Indonesia pada tahun 2009, demam tifoid dan paratifoid menempati urutan ketiga dari 10 penyakit terbanyak pasien rawat inap di rumah sakit sebanyak 80,850 kasus dengan korban meninggal 1,013 orang ${ }^{(4)}$.

Di daerah tropika lembab, perkembangan
serangga pembawa penyakit manusia
berlangsung dalam waktu yang singkat. Dalam
satu siklus hidup, perkembangan lalat
berlangsung selama 10 hari $\left(30^{\circ} \mathrm{C}\right), 21$ hari $(21$
o- ) dan 45 hari $\left(10^{\circ} \mathrm{C}\right)$ dan lalat rumah dewasa
mati pada suhu $0{ }^{\circ} \mathrm{C}^{(5)}$. Kejadian ini perlu
mendapat perhatian masyarakat daerah tropika
lembab seperti Indonesia, karena kesesuaian
kondisi dan singkatnya waktu perkembangan
lalat rumah. Peningkatan suhu di suatu wilayah
dapat menjadi salah satu ancaman
perkembangan serangga ini sehingga menjadi
ancaman juga bagi diakibat yang
ditimbulkannya.

Penelitian ini bertujuan untuk menganalisis pengaruh suhu udara terhadap daya tahan hidup dan periode perkembangan pradewasa lalat rumah (Musca domestica). Hasil penelitian ini diharapkan dapat bermanfaat sebagai komponen dari sistem kewaspadaan dini (Early warning system) perkembangan lalat di sekitar permukinan, sehingga pada akhirnya dapat bermanfaat untuk mengantisipasi kejadian penyakit yang ditularkannya.

\section{BAHAN DAN METODE}

\subsection{Metode Pengamatan}

Penelitian ini dilaksanakan pada bulan Desember 2012 sampai dengan April 2013 di Laboratorium Terpadu Geofisika dan Meteorologi, Institut Pertanian Bogor. Penelitian ini berupa percobaan laboratorium yang dilakukan melalui dua tahap. Tahap persiapan meliputi pemeliharaan lalat dewasa untuk mendapatkan telur yang akan diberi perlakuan suhu (rearing) dan penyediaan alat serta bahan penelitian. Tahap pemeliharaan pradewasa lalat rumah meliputi pemindahan masing-masing 80 telur ke empat media yang telah dicampur makanan ayam untuk masing-masing perlakuan suhu. Media tersebut dimasukan kedalam growth chamber dengan empat suhu perlakuan yang berbeda yaitu suhu $16^{\circ} \mathrm{C}, 27 \stackrel{\circ}{\circ} \mathrm{C}, 31^{\circ} \mathrm{C}$ dan $39{ }^{\circ} \mathrm{C}$ serta di tempat terbuka dengan suhu ambient, sebagai suhu kontrol. Pada stadium pupa dilakukan pemindahan media ke media baru (kandang lalat) untuk kemudian dimasukkan kembali ke dalam growth chamber dengan empat perlakuan suhu dan kontrol. Pengamatan selama perkembangan pradewasa dilakukan dua kali sehari setiap pukul 06.00 dan 18.00 WIB. Bahan penelitian yang digunakan di antaranya telur lalat rumah Musca domestica dari hasil rearing, makanan ayam (pellet), air dan gula. Alat yang digunakan adalah Growth Chamber model GC-300/1000, kandang lalat, wadah, kelambu, cawan petri, lup, pipet, dan termometer.

\subsection{Prosedur Analisis Data}

Pada penelitian ini, daya hidup (survival rate) dihitung dari persentase telur yang menetas menjadi larva (instar 1), larva (instar 1) menjadi pupa, pupa menjadi lalat dewasa (imago) serta dari telur menjadi lalat dewasa. Keragaman hasil pengamatan dalam kelompok perlakuan suhu yang sama karena keragaman sifat individu diatasi dengan menggunakan data modus. Analisis selanjutnya dilakukan terhadap data panjang periode perkembangan (longevity) dan laju perkembangan per hari. Pengaruh suhu pada daya tahan hidup pradewasa, panjang periode perkembangan pradewasa dan laju perkembangan pradewasa dianalisis 
menggunakan persamaan regresi dengan metode least square. Penentuan pola hubungan suhu dengan tahapan kehidupan lalat rumah ditentukan berdasarkan pertimbangan rasional dan nilai koefisien determinasi terbaik.

\section{HASIL DAN PEMBAHASAN}

\subsection{Pengaruh suhu udara terhadap daya tahan hidup pradewasa lalat rumah (Musca domestica)}

Berdasarkan hasil pengamatan pada empat suhu kamar yang berbeda dan satu suhu pada kondisi lingkungan bebas, diperoleh persentase telur yang menetas tertinggi terjadi pada suhu $27 \stackrel{\circ}{\circ}(86 \%)$ dan masih tinggi hingga pada suhu
$31 \stackrel{\circ}{ } \mathrm{C} \quad(76 \%)$, sedangkan persentase telur menetas terendah sebesar $34 \%$, terjadi pada suhu $16{ }^{\circ} \mathrm{C}$ (Tabel 1). Dari hasil pengamatan (Tabel 1), pengaruh suhu $(x)$ terhadap daya tetas telur (y) dapat dinyatakan dalam persamaan regresi $y=-0,26 x^{2}+15,60 x-147,4$ dengan koefisien determinasi $\left(R^{2}\right)$ sebesar $96 \%$ (Gambar 1). Hasil analisis ini menunjukan pengaruh suhu sangat nyata terhadap daya tetas telur lalat rumah menjadi larva 1. Berdasarkan persamaan kuadratik tersebut dapat diduga bahwa suhu optimum untuk daya tetas telur adalah sebesar $29^{\circ} \mathrm{C}$, sedangkan suhu terendah dan tertinggi untuk mendukung daya tetas telur adalah sebesar $12 \stackrel{\circ}{\circ} \mathrm{C}$ dan $47^{\circ} \stackrel{\circ}{ } \mathrm{C}$ (Tabel 2).

Tabel 1. Tingkat keberhasilan hidup pradewasa lalat rumah pada berbagai suhu

\begin{tabular}{llllll}
\hline Temp ( $\left.{ }^{\circ} \mathrm{C}\right)$ & E-L1 $(\%)$ & L1-P $(\%)$ & P-I (\%) & E-I (\%) & I (n) \\
\hline 16 & 33,8 & 48,1 & 46,2 & 7,5 & 6 \\
27 & 86,3 & 84,1 & 67,2 & 48,8 & 39 \\
31 & 76,3 & 67,2 & 70,7 & 36,3 & 29 \\
39 & 60,0 & 25,0 & 75,0 & 11,3 & 9 \\
Ambient & 81,3 & 84,6 & 87,3 & 60,0 & 48 \\
\hline
\end{tabular}

E: Eggs; L1: Larvae (instar 1); P: Pupa; I(n): (Number) imago from 80 eggs

Tabel 2 Hasil perhitungan suhu minimum, optimum, dan maksimum untuk daya hidup pradewasa lalat

\begin{tabular}{lccc}
\multicolumn{4}{c}{ rumah } \\
\hline & \multicolumn{3}{c}{ Room Temperatures ${ }^{\circ} \mathrm{C}$} \\
Dev. Stage & Minimum & Optimum & Maximum \\
\hline Eggs-Larvae1 & 12 & 29 & 47 \\
Larvae1-Pupae $^{\text {Pupae-Imago** }}$ & 10 & 26 & 41 \\
Eggs-Imagi $^{*}$ & 1.5 & 40 & 79 \\
\hline
\end{tabular}

**: Extrapolation result of the curve, not enough data to determine the reliable temperature limits

Persentase daya tahan hidup larva menjadi pupa tertinggi terjadi pada suhu $22^{\circ} \mathrm{C}(84 \%)$, sedangkan persentase terendah terjadi pada suhu $39{ }^{\circ} \mathrm{C}(25 \%)$. Pada suhu $39{ }^{\circ} \mathrm{C}$ larva mengalami kekeringan dan berubah warna menjadi warna hitam, sehingga tidak berkembang menjadi pupa. Pengaruh suhu $(\mathrm{x})$ terhadap daya tahan hidup larva menjadi pupa (y) dapat dinyatakan dalam persamaan regresi y
$=-0,32 x^{2}+16,87 x-137,82\left(R^{2}\right.$ sebesar $\left.98 \%\right)$. Berdasarkan analisis regresi tersebut didapatkan suhu optimum bagi daya tahan hidup larva menjadi pupa adalah sebesar $26{ }^{\circ} \mathrm{C}$. Dari persamaan tersebut juga menunjukkan suhu terendah dan tertinggi yang masih dapat mendukung daya tahan hidup larva lalat rumah adalah sebesar $10^{\circ} \mathrm{C}$ dan $41^{\circ} \mathrm{C}$ (Gambar 1 dan Tabel 2). 


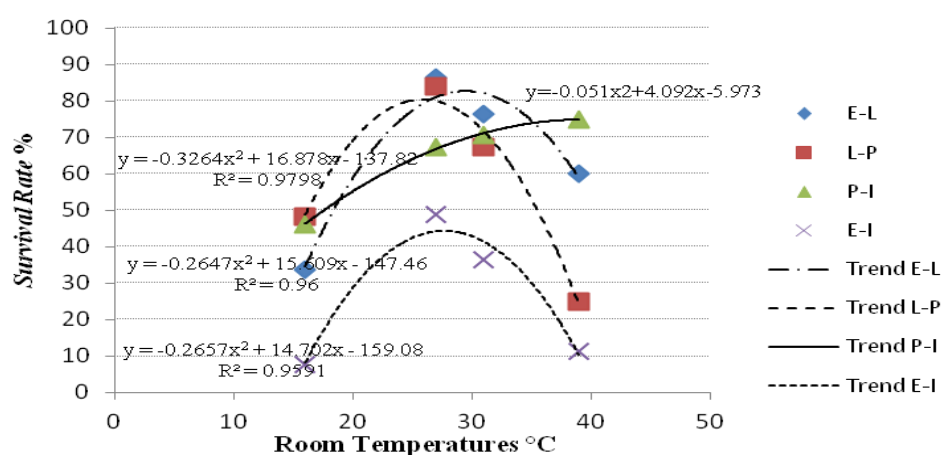

Gambar 1 Daya hidup pradewasa lalat rumah pada berbagai suhu

Persentase daya tahan hidup pupa menjadi lalat dewasa terendah terjadi pada suhu $16^{\circ} \mathrm{C}$ (46.2\%), sedangkan persentase tertinggi terjadi pada suhu $39^{\circ} \mathrm{C}$ sebesar $75 \%$. Berbeda dengan pada stadia lain, hingga suhu tertinggi yang dicobakan $\left(39^{\circ} \mathrm{C}\right)$, persentase daya tahan pradewasa lalat ini masih meningkat. Ini menunjukkan bahwa pupa sangat tahan atau tidak rentan dengan suhu tinggi. Pengaruh suhu (x) terhadap daya tahan hidup pupa menjadi dewasa $(y)$ dapat dinyatakan dalam persamaan regresi $y=-0,051 x^{2}+4,092 x-5.973$ dengan koefisien determinasi mendekati 1

Pengaruh suhu terhadap daya tahan hidup telur sampai dewasa dapat dinyatakan dalam bentuk persamaan regresi $y=-0,265 x^{2}+14,7 x$ 159,08 dengan koefisien determinasi sebesar 96 \% (Gambar 1). Berdasarkan bentuk persamaan tersebut dapat dinyatakan bahwa suhu optimal untuk perkembangan telur sampai dewasa terjadi pada suhu $28^{\circ} \mathrm{C}$. Ekstrapolasi dari persamaan yang diperoleh, suhu letal rendah dan tinggi untuk perkembangan pradewasa (telur - dewasa) masing-masing sebesar $15{ }^{\circ} \mathrm{C}$ dan 41 ㅇ. Hasil perhitungan tersebut menunjukan apabila suhu lebih rendah dari 15 ${ }^{\circ} \mathrm{C}$ dan lebih tinggi dari $41^{\circ} \mathrm{C}$, perkembangan pradewasa lalat rumah akan berhenti.

\subsection{Pengaruh suhu udara terhadap panjang periode perkembangan pradewasa lalat rumah (Musca domestica)}

Hasil pengamatan panjang periode perkembangan semua stadia pradewasa lalat rumah tercepat terjadi pada perlakuan suhu $39^{\circ} \mathrm{C}$. Panjang periode perkembangan pada suhu tersebut berlangsung selama 0.5 hari (telur-larva), 3 hari (larva-pupa) dan 3 hari (pupa-dewasa), dengan total 6.5 hari (telurdewasa). Suhu laboratorium yang dicobakan untuk mendukung periode perkembangan terpanjang adalah $16^{\circ} \mathrm{C}$, yaitu 2 hari (telurlarva), 6 hari (larva-pupa), 7.5 hari (pupadewasa), sehingga dari stadia telur menjadi dewasa diperlukan waktu selama 15.5 hari (Tabel 3).

Tabel 3 Panjang periode perkembangan (hari) pradewasa lalat rumah pada berbagai suhu

\begin{tabular}{lllll} 
Temperature $\left({ }^{\circ} \mathrm{C}\right)$ & $\mathrm{E}-\mathrm{L}$ & $\mathrm{L}-\mathrm{P}$ & $\mathrm{P}-\mathrm{I}$ & $\mathrm{E}-\mathrm{I}$ \\
\hline 16 & 2 & 6 & 7.5 & 15.5 \\
27 & 2 & 4.5 & 4 & 10.5 \\
31 & 0.5 & 3.5 & 3.75 & 7.75 \\
39 & 0.5 & 3 & 3 & 6.5 \\
Ambient & 1.5 & 5 & 3 & 9.5 \\
\hline
\end{tabular}

E: Eggs; L1: Larvae instar 1; P: Pupae; I: Imago

Hubungan antara suhu dan panjang periode tahap-tahap perkembangan pradewasa mengikuti persamaan exponensial, artinya semakin tinggi suhu semakin cepat tahap perkembangannya. Bentuk hubungan yang sama didapatkan dalam perkembangan serangga nyamuk Aedes aegyti ${ }^{(6)}$. Bentuk persamaan hubungan antara suhu dan panjang periode tetas telur adalah $y=6.850 \mathrm{e}^{-0,06 x}$ dengan koefisien determinasi sebesar $66 \%$, perkembangan larva menjadi pupa mengikuti pola persamaan $y=9.908 e^{-0,03 x}\left(R^{2}=97 \%\right)$, perkembangan pupa menjadi dewasa dalam bentuk persamaan $y=13.24 \mathrm{e}^{-0,04 x}\left(R^{2}=95 \%\right)$, dan untuk keseluruhan periode pradewasa dari telur hingga dewasa membentuk persamaan $\mathrm{y}=$ $28.77 e^{-0,04 x}\left(R^{2}=97 \%\right)$ (Gambar 2). 


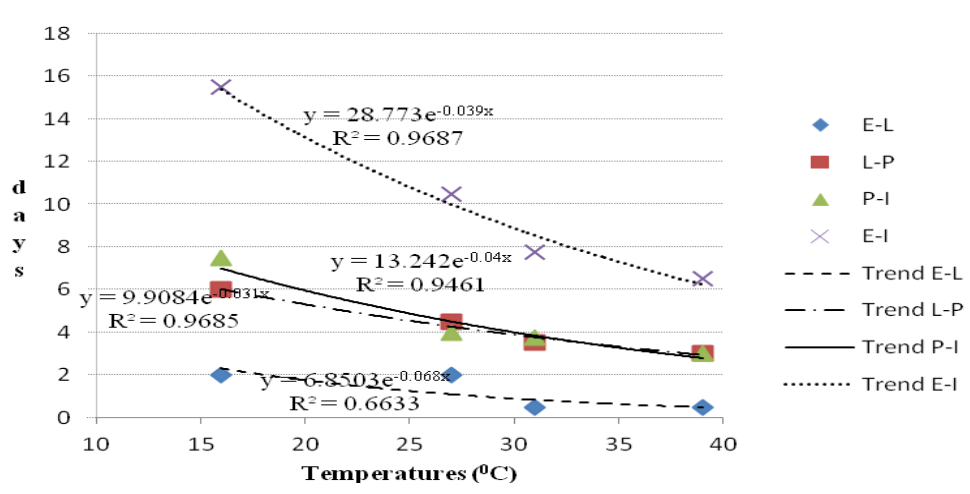

Gambar 2 Pengaruh suhu terhadap panjang periode perkembangan pradewasa lalat rumah

Berdasarkan hasil pengamatan pada suhu tinggi, periode perkembangan pradewasa lalat akan cepat, sedangkan pada suhu yang lebih rendah dari suhu optimum, laju metabolisme dan aktivitasnya rendah sehingga perkembangannya lambat. Bentuk persamaan hubungan antara suhu dan periode perkembangan seluruh periode pradewasa lalat rumah $(\mathrm{y})$ adalah $\mathrm{y}=42,67 \mathrm{e}^{-0,04 \mathrm{x}}$ dengan koefisien determinasi sebesar 95\%. Suhu berpengaruh sangat nyata terhadap periode perkembangan pradewasa lalat rumah.

\subsection{Pengaruh suhu udara terhadap laju perkembangan pradewasa lalat rumah (Musca domestica)}

Berdasarkan hasil pengamatan di media terkontrol, suhu $16^{\circ} \mathrm{C}$ mendukung laju perkembangan lalat per hari terkecil dan suhu $31^{\circ} \mathrm{C}$ mendukung laju perkembangan terbesar. Bentuk persamaan laju perkembangan pradewasa lalat rumah pada berbagai suhu adalah $y=-0,027 x^{2}+1,567 x-17,57$ dengan koefisien determinasi hampir sempurna (Gambar 3). Dari persamaan kuadratik tersebut menunjukan laju perkembangan optimum terjadi pada suhu $28^{\circ} \mathrm{C}$, dan dengan ekstrapolasi diperoleh suhu minimum yang masih mendukung perkembangan pradewasa lalat rumah adalah sebesar $16^{\circ} \mathrm{C}$ dan suhu maksimumnya $42^{\circ} \mathrm{C}$. Pada suhu yang kurang dari $16^{\circ} \mathrm{C}$ dan lebih dari $42^{\circ} \mathrm{C}$, perkembangan lalat rumah akan berhenti.

Tabel 4. Laju perkembangan telur menjadi imago pada berbagai suhu

\begin{tabular}{lccc}
\hline Temperatures $\left({ }^{\circ} \mathrm{C}\right)$ & \% Survival & Days $^{*}$ & Survival Rate $(\% /$ day $)$ \\
\hline 16 & 7.5 & 15.5 & 0.48 \\
27 & 48.8 & 10.5 & 4.65 \\
31 & 36.3 & 7.75 & 4.68 \\
39 & 11.3 & 6.5 & 1.74 \\
Ambient & 60.0 & 9.5 & 6.32 \\
\hline
\end{tabular}

Note * : longevity of immature house flies

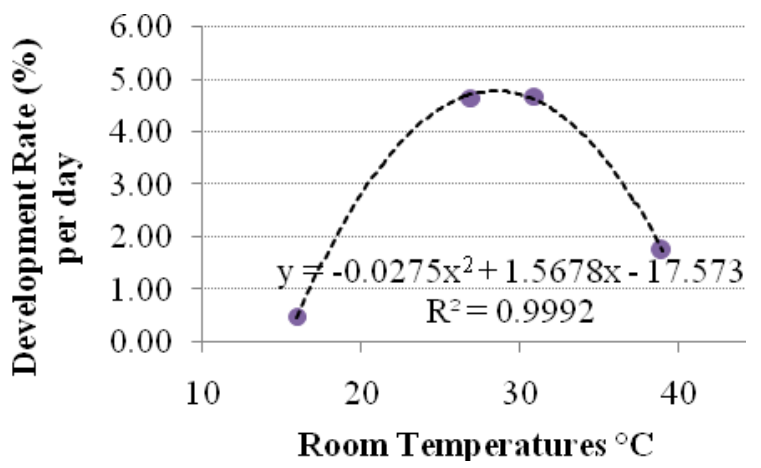

Gambar 3. Laju perkembangan telur menjadi imago pada berbagai suhu 


\section{PEMBAHASAN}

Dalam satu siklus hidupnya, lalat rumah mengalami empat stadia yaitu telur, larva, pupa dan imago atau lalat dewasa. Pada setiap stadia, suhu lingkungan mempengaruhi daya tahan hidup dan waktu perkembangan pradewasa. Daya tahan hidup setiap stadium dinyatakan dalam persentase keberhasilan tiap stadium tersebut untuk berkembang menjadi stadium berikutnya, yaitu dari telur hingga dewasa.

Pada perubahan seluruh stadia, persentase daya tahan hidup dan laju perkembangan tertinggi terjadi pada perlakuan kontrol di luar growth chamber, kecuali pada perubahan dari telur ke larva1 (Tabel 1). Selain itu, persentase laju perkembangan lalat per hari lebih tinggi pada kondisi kontrol (lingkungan bebas/ ambient) dari perlakuan suhu di laboratorium . Lingkungan bebas mempunyai karakter suhu, radiasi, kelembaban, oksigen dan kondisi lainnya yang berfluktuasi, mengikuti kondisi udara bebas. Kondisi ini diperkirakan lebih cocok untuk perkembangan pradewasa lalat rumah. Hal ini menunjukkan bahwa kombinasi faktor iklim dan faktor lingkungan bebas pada wilayah penelitian lebih sesuai jika dibandingkan dengan perlakuan di dalam growth chamber. Berdasarkan persamaan kuadratik tiap stadia menunjukan bahwa suhu optimum perkembangan lalat rumah berada pada rentang suhu daerah tropis yaitu sekitar $22^{\circ} \mathrm{C}-32^{\circ} \mathrm{C}$, sehingga perlu diwaspadai oleh masyarakat yang tinggal di daerah tropis. Ketika berada di luar rentang suhu daerah tropis, daya tahan hidup lalat rumah akan rendah, seperti pada suhu $16 \stackrel{\circ}{\circ}$ yang tingkat keberhasilan hidup telurnya rendah sekitar $34 \%$. Daya tetas telur yang rendah tersebut terjadi karena telur mengalami kekeringan pada kelembaban mutlak rendah, karena telur menjadi steril sehingga tidak terbentuk embrio ${ }^{(7)}$.

Berdasarkan hasil pengamatan, panjang periode perkembangan pada semua stadia kehidupan lalat bervariasi menurut suhu udara, sesuai dengan pendapat yang menyatakan bahwa suhu mempengaruhi perkembangan lalat rumah $^{(5)}$. Menurut ${ }^{(8)}$, perkembangan telur pada perlakuan di laboratorium dengan lingkungan bebas akan berbeda. Perkembangan di laboratorium akan lebih cepat bila dibandingkan pada suhu lingkungan bebas, karena kemampuan adaptasi telur lalat rumah pada suhu laboratorium yang relatif konstan lebih tinggi dari kemampuan adaptasi pada suhu lingkungan bebas yang berubah-ubah.

Semakin meningkat suhu hingga mencapai suhu optimum, periode perkembangan pradewasa lalat rumah akan semakin cepat. Pengaruh suhu pada kecepatan perkembangan mempengaruhi jumlah populasi lalat rumah dalam satu periode. Pada suhu di sekitar suhu optimum, peluang berkembangnya penyakit yang diakibatkan oleh lalat rumah dapat mencapai optimum. Dengan demikian maka jika suatu daerah mengalami kenaikan suhu dalam periode musiman atau jangka panjang, ancaman serangan lalat rumah berpotensi meningkat karena kenaikan suhu mengakibatkan periode perkembangan lalat rumah semakin cepat. Selain itu, biasanya meningkatnya suhu menyebabkan peningkatan metabolisme dan berakibat kepada sifat atau prilakunya seperti akitivitas, keberanian, agresivitas dan eksplorasi dari serangga tersebut $^{(9,10,11,12,13)}$. Pada suhu yang tinggi, sifat prilaku seperti terbang dan kawin tampaknya akan dipengaruhi secara negatif oleh panas $^{(14,15)}$.

Pada serangga, ketahanan panas sering berbeda antar tahapan stadia yang dihubungkan dengan mobilitas (gerak) tiap stadia ${ }^{(16,17)}$, seperti pada stadia telur dan pupa serangga D.Buzzati menunjukan batas ketahanan panas yang lebih tinggi dari stadia bergerak (larva dan dewasa) ${ }^{(18)}$.

Hasil dari penelitian ini dapat dimanfaatkan untuk mengantisipasi ancaman berkembangnya penyakit yang ditularkan lalat rumah oleh keragaman dan perubahan iklim, terutama suhu udara karena banyak spesies lalat rumah yang dijumpai di gradient lintang dan telah beradaptasi secara fisiologis dan morfologis terhadap kondisi suhu local ${ }^{(19,20,21,22,23)}$. Peran lalat rumah dalam penyebaran penyakit dan penyebab efek psikologis negatif dapat dikurangi di antaranya dengan mengurangi atau menghilangkan tempat perindukan / perkembangbiakan lalat rumah, mengurangi sumber yang menarik lalat rumah, dan mencegah kontak antara lalat dengan kotoran yang mengandung kuman penyakit. Kebersihan lingkungan pada periode atau wilayah dengan suhu tinggi (dataran rendah) perlu lebih sering dilakukan daripada periode atau wilayah yang lebih rendah suhunya (dataran tinggi). Perkembangan pradewasa lalat rumah yang meliputi daya tahan hidup dan laju perkembangan pradewasa terjadi pada suhu optimum sebesar $28^{\circ} \mathrm{C}$. Di sebagian besar wilayah dataran rendah Indonesia mempunyai kisaran suhu rata-rata bulanan sebesar $26^{\circ} \mathrm{C}$ sampai $28^{\circ} \mathrm{C}$, menjadi daerah yang sangat cocok untuk perkembangan pradewasa lalat rumah, terutama pada periode akhir musim kemarau, dimana kelembaban juga cukup tinggi. 


\section{KESIMPULAN}

Suhu udara mempengaruhi daya tahan hidup (survival rate) dan periode perkembangan (longevity) pradewasa lalat rumah. Suhu tinggi dan rendah dapat mengakibatkan daya tahan hidup lalat rumah rendah. Suhu optimum untuk daya tahan hidup dan laju perkembangan pradewasa (perkembangan telur sampai dewasa) lalat rumah sebesar $28 \stackrel{\circ}{ } \mathrm{C}$ dengan suhu letal rendah dan tinggi masing-masing sebesar $16{ }^{\circ} \mathrm{C}$ dan $42{ }^{\circ} \mathrm{C}$. Pola hubungan antara suhu dengan daya tahan hidup serta laju perkembangan pradewasa per hari berbentuk kurva kuadratik. Pola hubungan pengaruh suhu terhadap periode perkembangan (longevity) pradewasa membentuk kurva yang berbeda dengan hubungan antara suhu dengan daya tahan hidup. Peningkatan suhu juga mempercepat periode perkembangan pradewasa mengikuti pola persamaan eksponensial.

\section{PERSANTUNAN}

Penulis mengucapkan terima kasih kepada Staf Pengajar dan Departemen Geosfisika dan Meteorologi dan Fakultas Kedokteran Hewan IPB yang telah mendukung penelitian ini.

\section{DAFTAR PUSTAKA}

1. Molyneux D, Hallaj Z, Keusch GT, McManus DP, Ngowi H, Cleaveland S, Jimenez PR, Gotuzzo E, Kar K, Sanchez A, Garba A, Carabin $\mathrm{H}$, Bassili A, Chaignat CL, Meslin FX, Abushama HM, Willingham AL, Kioy D. (2011),. Zoonoses and Marginalized Infectious Diseases of Poverty: Where do we stand?. Parasites and Vectors 4:106 (http//www:parasitesandvectors.com/content/ 4/1/106)

2. Malik A, Singh N, Satya S., (2007), House fly (Musca domestica): A review of control strategies for a challenging pest. Journal of Environmental Science and Health, Part B: Pesticides, Food Contaminants, and Agricultural Wastes. 42(4):453-469. doi:10.1080/03601230701316481.

3. Melsinawati W, Khotimah S, Rizalinda,(2012), Jamur yang terdapat pada tubuh lalat rumah (Musca domestica L., 1758). Protobiont, 1(1): 12-19

4. Kementerian Kesehatan RI., (2010), Profil Kesehatan Indonesia Tahun 2009. Jakarta (ID): Kementerian Kesehatan RI.
5. Burgess P., (2013), The biology and lifecycles of common flies on livestock operations. IPM Coordinator. Perennia.

6. Hidayati, R., Kesumawati, U., Manuwoto, S., Boer, R., dan Koesmayono, Y., (2007), Kebutuhan Satuan Panas untuk Fase Perkembangan pada Nyamuk Aedes aegypti (Diptera: Culicidae) dan Periode Inkubasi Ekstrinsik Virus Dengue (Heat Unit Requirement for Development stages of Aedes aegypti and Extrinsic Incubation period of Dengue Virus). J. Ekol. Kes. 6(3):648-658.

7. Sutherst RW., (2004), Global change and human vulnerability to vector- borne disease. Clinical Microbiology Reviews. 17(1):136173. doi:10.1128/CMR.17.1.136-173.2004.

8. Elvin MK, Krafsur ES., (1984), Relationship between temperature and rate of ovarian development in the house fly, Musca domestica L. (Diptera: Muscidae). Annals of the Entomological Society of America. 77(1):50-55(6).

9. Biro PA, Stamps JA., (2008), Are animal personality traits linked to life-history productivity?Trends in Ecology\&Evolution, 23,361-368

10.Briffa M, Bridger D, Biro PA., (2013), How does temperature affect behaviour? Multilevel analysis of plasticity, personality and predictability in hermit crabs. Animal Behaviour, 86,47-54

11.Careau V, Thomas D, Humphries MM, Reale D., (2008), Energy metabolism and animal personality.Oikos, 117,641-653.

12. Houston A I., (2010), Evolutionary models of metabolism, behaviour and personality.Philosophical Transactions of the Royal Society B: Biological Sciences, 365, 39693975

13. Huey RB, Hertz PE, Sinervo B., (2003), Behavioral drive versus behavioral inertia in evolution: a null model approach. American Naturalist, 161,357-366

14.Krebs RA, Thompson KA., (2006), Direct and correlated effects of selection on flight after exposure to thermal stress inDrosophila melanogaster. Genetica, 128, 217-225

15.Patton Z J, Krebs RA., (2001), The effect of thermal stress on the mating behavior of threeDrosophilaspecies.Physiological and Biochemical Zoology, 74, 783-788

16.Bowler, K. \& Terblanche, J.S., (2008), Insect thermal tolerance: what is the role of 
ontogeny, ageing and senescence? Biological Reviews, 83, 339-355.

17.Marais, E. \& Chown, S.L., (2008), Beneficial acclimation and the Bogert efect. Ecology Letters, 11, 1027-1036.

18.Krebs, R. A., \& Loeschcke, V., (1995), Resistance to thermal stress in preadult Drosophila buzzatii: variation among populations and changes in relative resistance across life stages. Biological Journal of the Linnean Society, 56, 517-531

19.Bahrndorff S, Holmstrup M, Petersen $H$, Loeschcke V., (2006), Geographic variation for climatic stress resistance traits in the springtailOrchesella cincta. Journal of Insect Physiology, 52,951-959

20.Bubliy OA, Riihimaa A, Norry FM, Loeschcke V., (2002), Variation in resis-tance and acclimation to low-temperature stress among three geographical strains of Drosophila melanogaster. Journal of Thermal Biology, 27,337-344.

21.Dahlgaard J, Hasson E, Loeschcke V., (2001), Behavioral differentiation in oviposition activity inDrosophila buzzatiifrom highland and lowland pop-ulations in Argentina: plasticity or thermal adaptation?Evolution, 55,738-747

22.Gibert P, Huey RB, Gilchrist GW., (2001), Locomotor performance of Drosophila melanogaster: interactions among developmental and adult tem-peratures, age, and geography. Evolution, 55, 205-209

23.Karl I, Sorensen JG, Loeschcke V, Fischer K., (2009), HSP70 expression in the Copper butterfly Lycaena tityrusacross altitudes and temperatures.Journal of Evolutionary Biology, 22,172-178 